\title{
Impelementasi Pembelajaran Konstruktivis untuk menumbuhkan karakter kerja keras pada siswa
}

\author{
Lenny Kurniati \\ Jurusan Pendidikan Matematika, IKIP Veteran Jawa Tengah \\ Jl. Pawiyatan Luhur IV/17 Semarang \\ Lennykurniati@gmail.com
}

\begin{abstract}
Pendidikan karakter menjadi salah satu agenda pendidikan nasional Indonesia. Pelaksanaan pendidikan karakter di Indonesia terintegrasi dalam proses pembelajaran setiap mata pelajaran, termasuk dalam pelajaran matematika. Matematika sebagai ilmu yang mendasar dan diselenggarakan di setiap jenjang pendidikan mulai pendidikan dasar hingga pendidikan tinggi, menjadi salah satu media implementasi pendidikan karakter di sekolah. Model dan pendekatan yang tepat perlu dirancang dan direncanakan sedemikian rupa, sehingga pendidikan karakter dapat terlaksana dan karakter yang diharapkan dapat dicapai oleh peserta didik. Pembelajaran semacam ini disebut pembelajaran by design, salah satunya adalah pembelajan matematika konstruktivis dengan pendekatan inkuiri guna menumbuhkan karakter kerja keras pada peserta didik. Penelitian yang dilaksanakan dalam bentuk kualitatif deskriptif ini menunjukkan bahwa pembelajaran matematika konstruktivis dengan pendekatan inkuiri dapat menumbuhkan dan meningkatkan karakter kerja keras pada peserta didik. Pembelajaran by design sejenis ini diharap dapat dikembangkan dan menjadi solusi dalam mengintegrasikan pendidikan karakter dalam pembelajaran.
\end{abstract}

Kata Kunci: pendidikan karakter, kerja keras, matematika, konstruktivis, inkuiri.

Character education become one of agenda of education of Indonesia national. integrated character Education Execution in Indonesia in course of study each;every subject, included in mathematics Iesson. Mathematics as elementary science and carried out in each;every education ladder start the elementary education till higher education, becoming one of media of implementation of character education at school. Model and correct approach require to be designed and planned in such a manner, so that character education can be executed and character expected reachable by competitor educated. Study of a kind of this referred as by study of by design, one of them is is pembelajan of mathematics konstruktivis with the approach inkuiri utilize to grow the character hard work at competitor educated. Research executed in the form of descriptive qualitative indicate that the study of mathematics konstruktivis with the approach inkuiri can grow and improve the character hard work at competitor educated. study of By design of a kind this hoped can be developed and become the solution in integrating character education in study.

Keyword: character Education, hard works, mathematics, conctructivis, inquiri.

\section{PENDAHULUAN}

Pendidikan adalah usaha sadar dan terencana untuk mewujudkan sarana belajar dan proses pembelajaran agar peserta didik secara aktif mengembangkan potensi dirinya untuk memiliki kekuatan spiritual keagamaan, pengendalian diri, kepribadian, kecerdasan, akhlak mulia, serta keterampilan yang diperlukan dirinya dan masyarakat (Kemendiknas, 2003). Kualitas Pendidikan menunjukkan kualitas suatu bangsa. Perwujudan bangsa yang berkualitas menjadi tanggung jawab pendidikan. Menyadari hal tersebut, pemerintah melakukan berbagai upaya perbaikan pada sistem pendidikan Indonesia, salah satu diantaranya adalah dengan mencanangkan pendidikan karakter yang terintegrasi dalam setiap aspek pendidikan.

Pendidikan karakter menjadi fokus Kementrian pendidikan Nasional, dan diterapkan di seluruh jenjang pendidikan. Pendidikan nasional bertujuan untuk mengembangkan kemampuan dan membentuk karakter serta peradaban bangsa yang bermartabat dalam rangka mencerdaskan kehidupan bangsa (Kemendiknas, 2003). Kementrian Pendidikan Nasional juga telah mencanangkan pendidikan karakter secara nasional sejak tanggal 2 mei 2010. 
Nilai-nilai dasar pendidikan karakter bangsa memilik 18 nilai karakter, yaitu sebagai berikut: (1) bertaqwa, (2) bertanggung jawab, (3) disiplin, (4) jujur, (5) toleransi, (6) kerja keras, (7) kreatif, (8) mandiri, (9) rasa ingin tahu, (10) semangat kebangsaan, (11) menghargai, (12) bersahabat, (14) cinta damai, (15) demokratis, (16) peduli lingkungan, (17) gemar membaca, dan (18) cinta tanah air. Karakter tersebut yang harus diintegrasikan dalam pendidikan sehingga dapat meningkatkan kualitas peserta didik tidak hanya kognitif tetapi juga afektifnya dipandang dari karakter-karakter tersebut di atas.

Matematika sebagai salah satu ilmu yang mendasar mempunyai ruang lingkup materi atau bahan kajian yang sangat luas. Kesadaran akan matematika sebagai alat komunikasi dan alat berpikir, kegunaan untuk berbagai bidang ilmu, teknologi dan masyarakat serta kegunaannya bagi kehidupan sehari-hari telah menjadikan matematika dipelajari secara luas dan mendasar sejak jenjang pendidikan yang terendah sampai ke perguruan tinggi.

Pembelajaran matematika merupakan bagian dari pendidikan masional yang menyumbang-kan kontribusi penting dalam pembentukan karakter siswa. Beberapa ciri khusus dari matematika antara lain: (1) memiliki objek kajian abstrak, berdasarkan pada kesepakatan, (3) berpola pikir deduktif, (4) memiliki simbol yang kosong dari arti, dan (5) memperhatikan semesta pembicaraan (Soedjadi, 2000). Karakteristik matematika seperti tersebut di atas menunjukkan bahwa matematika sebagai ilmu yang menunjang terbentuknya karakter-karakter sesuai yang dideskripsikan sebelumnya. Melalui pembelajaran matematika, peserta didik diharapkan dengan sendirinya terbentuk karakter seperti; cermat, mampu berpikir kritis, kreatif, kerja keras, jujur, taat aturan, demokratis, dan sebagainya.

Matematika adalah ilmu yang didasarkan pada suatu kesepakatan. Para pelaku matematika tentu sudah terbiasa dengan aturan-aturan dan kesepakatan yang terdapat dalam ilmu matematika. Kesepakatan dalam matematika itu dapat berupa simbol, lambang, istilah, konsep, definisi, serta aksioma. Seseorang yang telah menjiwai matematika tentu memiliki karakter taat aturan dan juga disiplin. Ciri matematika yang lain adalah memiliki objek abstrak dan berpola deduktif, hal ini akan memunculkan karakter kreatif pada seseorang yang belajar matematika. Karakter lain yang juga dapat muncul adalah karakter kerja keras, dimana peserta didik harus dapat menyelesaikan berbagai permasalahan matematika yang rumit dan diperlukan effort yang tinggi untuk menyelesaikannya.

Karakter yang muncul dengan sendirinya melalui proses pembelajaran matematika disebut sebagai pembelajaran by chance, sedangkan pembelajaran yang dirancang sejak awal dengan memasukkan aspek karakter sebagai capaian pembelajaraannya, disebut sebagai pembelajaran by design (Soedjadi, 2000). Pelaksanaan pembelajaran by design, dapat berjalan dengan lancar jika rancangannya baik, termasuk didalamnya pendekatan, model, dan strategi yang digunakan harus tepat.

Seiring dengan perkembangan matematika, maka diperlukan suatu pembelajaran yang secara sengaja memasukkan pembelajaran nilai-nilai karakter ke dalam perencanaan pembelajaran sehingga tujuan untuk membentuk karakter siswa melalui proses pembelajaran matematika dapat dicapai (Fadillah, 2013). Berbagai teori belajar, model, strategi, ataupun pendekatan pembelajaran dapat digunakan sebagai media penanaman nilai-nilai karakter bangsa. Salah satunya adalah model pembelajaran konstruktivis, dimana siswa dituntut harus mengkonstruk pengetahuannya sendiri. Model ini akan sangat cocok bila disandingkan dengan pendekatan inkuiri, dimana pembelajaran berpusat pada siswa, sehingga guru hanya berperan sebagai fasilitator. Rancangan pembelajaran semacam ini diharapkan dapat memunculkan karakter-karakter positif dalam diri peserta didik, diantaranya adalah karakter mandiri, kerja keras, teliti, dan sebagainya.

Konstruktivisme adalah suatu teori belajar yang berarti menciptakan, artinya individu menciptakan pemahaman baru mereka atas dasar interaksi antara hal sudah mereka ketahui dan percaya, ide-ide, dan pengetahuan yang mereka dapatkan (Richardson, 2003). Konstruktivisme dalam penelitian ini merujuk pada kegiatan belajar dimana peserta didik dapat membangun pengetahuannya sendiri, dengan 
bermodalkan pengetahuan-pengetahuan lama yang telah dimiliki sebelumnya, sehingga membentuk informasi yang baru.

Pembelajaran inkuiri adalah sebuah pendekatan pembelajaran yang langsung terpusat pada peserta didik yang mana nantinya kelompok-kelompok siswa tersebut akan dibawa dalam persoalan maupun mencari jawaban atas pertanyaan sesuai dengan struktur dan prosedur yang jelas. Inkuiri adalah salah satu strategi yang digunakan dalam kelas yang berorientasi proses, inkuiri merupakan sebuah strategi pengajaran yang berpusat pada siswa (Putrayasa, 2009). Lima tahapan yang ditempuh dalam pelaksanaan pembelajaraan inkuiri yaitu: (1) perumusan masalah yang dipecahkan siswa, (2) menetapkan jawaban sementara, (3) siswa mencari informasi, data, dan fakta yang diperlukan untuk menjawab pertanyaan, (4) menarik kesimpulan jawaban, dan (5) mengaplikasikan kesimpulan dalam situasi baru (Sagala, 2006).

Pendekatan inkuiri dalam penelitian ini merancang guru sebagai fasilitator belajar para peserta didik. Guru memberikan bantuan berupa petunjuk-petunjuk kepada peserta didik ketika proses menyelesaikan masalah, guru memberikan bimbingan, sehingga peserta didik dapat merecall materi yang telah dipelajari sebelumnya, untuk kemudian dikonstruk dengan pengetahuan baru sehingga dapat memecahkan masalah.

Duet maut antara model konstruktivis dan pendekatan inkuiri, merupakan perpaduan yang cocok untuk menanamkan dan menumbukan nilai-nilai karakter bangsa. Salah satu karakter yang akan diamati dalam penelitian ini adalah karakter kerja keras. Peserta didik diharap mampu mengembangkan karakter kerja keras, tidak mudah putus asa, dan terus bersemangat dalam belajar. Adapun indikator kerja keras menurut Wuryanto, antara lain: (1) pantang menyerah dalam menghadapi berbagai kesulitan dalam melaksanakan kegiatan pembelajaran, (2) mencari strategi untuk mengatasi kesulitan dengan pemikirannya, (3) menyelesaikan tugas dengan baik dan tepat waktu, (4) berupaya mencaari sumber belajar dan informasi tentang konsep yang dipelajari, (5) mengajukan ide dan pendapat dalam setiap diskusi, dan (6) memiliki etos kerja yang tinggi (Kurniyati, 2013).
Berdasarkan uraian di atas, penelitian ini bertujuan untuk menganalisa proses pembentukan karakter kerja keras melalui pembelajaran matematika dengan model konstruktivis dan pendekatan inkuiri.

\section{METODOLOGI}

\section{Populasi dan Sampel}

Populasi dari penelitian ini adalah seluruh siswa kelas X SMA Sint Louis Semarang. Alasan pemilihan sekolah ini antara lain; sekolah ini terbuka untuk penelitian, berdasarkan studi pendahuluan dengan guru matematika di sekolah ini diketahui bahwa pembentukkan karakter kerja keras belum tampak pada saat pembelajaran.

Teknik pengambilan sampel menggunakan teknik nonprobability sampling dengan jenis purposive sampling. Dipilih 5 subjek penelitian dengan kriteria sebagai berikut.

(1) Siswa yang bersedia dengan sukarela menjadi subjek penelitian (willingness). Sukarela yang dimaksud adalah keputusan untuk menjadi subjek penelitian tanpa ada paksaan atau tekanan dari luar, seperti sekolah atau guru. Hal ini dimaksudkan agar subjek penelitian bersungguh-sungguh dalam mengikuti semua kegiatan penelitian sehingga data yang diperoleh baik. (2) Siswa yang dipilih memiliki kemampuan yang heterogen (diverse mathematical background). Lima siswa yang dipilih yaitu: (a) dua siswa dengan tingkat kemampuan tinggi (kelompok 10\% siswa dengan kemampuan teratas dalam matematika), (b) satu siswa dengan tingkat kemampuan sedang (kelompok siswa dengan kemampuan rata-rata dalam matematika), dan (c) dua siswa dengan tingkat kemampuan kurang (kelompok 10\% siswa dengan kemampuan terendah dalam matematika).

Kelima siswa tersebut adalah OD dan AD sebagai peserta didik dengan kemampuan kognitif rendah, EF sebagai peserta didik berkemampuan kognitif sedang, WA dan AS sebagai peserta didik berkemampuan kognitif tinggi.

\section{Desain Penelitian}


Penelitian ini termasuk dalam penelitian kualitatif deskriptif. Penelitian kualitatif adalah prosedur penelitian yang menggunakan data deskriptif berupa katakata tertulis atau lisan dari otang-orang dan perilaku yang (Moleong, 2009). Penelitian ini menggunakan perhitungan sedarhana berupa uji gain ternormalisasi sebagai informasi pelengkap.

Adapun alasan penelitian ini menggunakan pendekatan kualitatif adalah karena dalam penelitian ini, data yang dihasilkan berupa tulisan, kata-kata, dan dokumen yang berasal dari sumber atau informan yang diteliti dan dapat dipercaya. Penelitian ini akan melihat proses pembentukan karakter khususnya karakter kerja keras pada siswa kelas X SMA Sint Louis Semarang melalui pembelajaran kooperatif Inkuiri.

Sumber data yang digunakan dalam penelitian ini antara lain sumber data primer dan sumber data sekunder. Sumber data primer adalah sumber data yang diperoleh dari lapangan. Data ini diperoleh melalui wawancara dengan responden maupun informan. Responden dalam penelitian ini adalah 5 orang siswa kelas X SMA Sint Louis Semarang, sedangkan informan pada penelitian ini adalah guru matematika. Sumber data sekunder adalah sumber data dari dokumen-dokumen dan literature yang ada kaitannya dengan tema permasalahan.

Teknik pengumpulan data yang digunakan adalah wawancara, pengamatan, dan dokumentasi. Wawancara adalah percakapan yang dilakukan oleh dua pihak yaitu pewawancara dan yang diwawancarai yang memberikan jawaban atas pertanyaan (Moleong, 2009). Pengamatan atau observasi dilakukan untuk mendeskripsikan setting, kegiatan yang terjadi, orang yang terliabt dalam kegiatan, waktu kegiatan, dan makna yang diberikan oleh pelaku yang diamati tentang peristiwa yang diamanti (Asshofa, 2001). Dokumentasi adalah menghimpun data mengenai hal atau variabel yang berupa catatan, transkrip, majalah, notulen, dan lain sebagainya.

Teknik pemeriksaan data untuk mengecek kembali keabsahan data pada penelitian ini dilakukan triangulasi data. Teknik triangulasi adalah teknik pemeriksaan keabsahan data yang memanfaatkan sesuatu yang lain di luar data itu untuk keperluan pengecekan atau sebagai pembading (Moleong, 2009).
Triangulasi yang digunakan dalam penelitian ini adalah triangulasi sumber, yaitu dengan mengecek dan membandingkan kepercayaan suatu informasi yang diperoleh melalui alat dan waktu yang berbeda dalam metode kualitatif. Proses triangulasi yang dilakukan peneliti dapat digambarkan seperti di bawah ini:

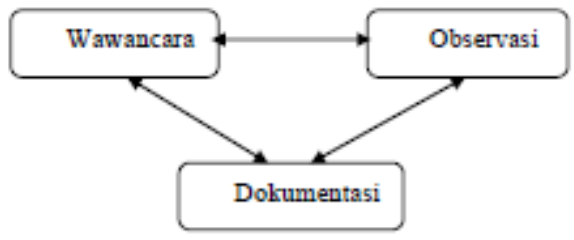

Gambar 1. Triangulasi Sumber (Sugiyono, 2008)

\section{Alur Pengolahan Data}

Proses pengolahan atau analisis data dimulai dengan menelaah semua yang tersedia dari berbagai sumber yaitu wawancara, pengamatan yang sudah dituliskan dalam catatan lapangan, dokumen pribadi, dokumen resmi, gambar, foto, dan sebagainya (Moleong, 2009). Pengolahan data kualitatif dilakukan dalam empat tahap yaitu; pengumpulan data, reduksi data, penyajian data, dan pengambilan keputusan atau verifikasi (Hubberman, 1992). Proses pengolahan data kualitatif digambarkan dalam alur berikut:

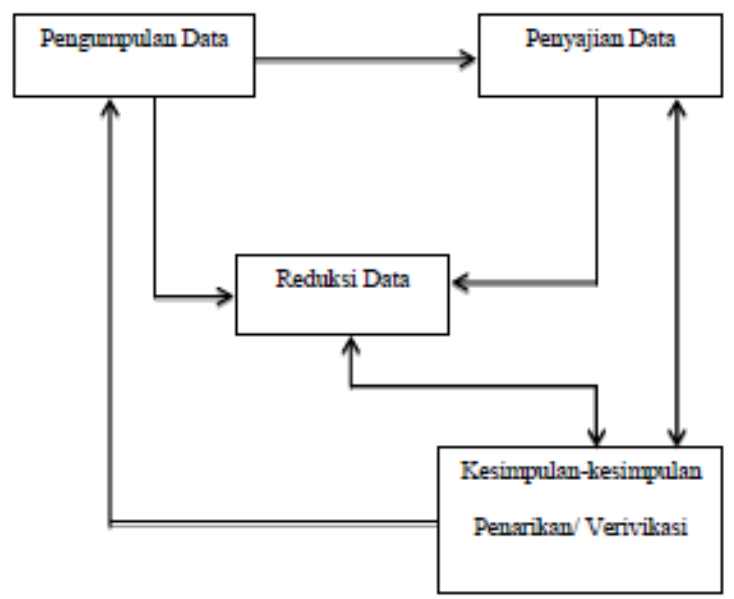

Gambar 2. Komponen-komponen analisis data ( Miles \& Hubberman, 1992)

\section{HASIL DAN PEMBAHASAN}

Hasil data penelitian ini diperoleh dengan cara wawancara, mengamati dan membuat dokumentasi proses pembelajaran yang difokuskan kepada lima orang siswa yaitu 
OD, AD, EF, WA dan AS. Pengamatan dan wawancara dilakukan di saat siswa melakukan pembelajaran dengan model konstruktivis dan pendekatan inkuiri, pada lingkungan yang sama.

Berikut adalah hasil wawancara awal mengenai

Hasil wawancara dengan OD sebagai berikut:

P : "apakah kamu menyukai pelajaran matematika?"

$O D$ : "nggak suka, susah Bu, ribet rumusnya"

$P$ : "merasa susahnya dimana?"

$O D$ : "nggak mudeng bu"

$P$ : "tidak mudengnya karena faktor apa kira-kira?"

OD : "tidak paham yang dijelaskan pak Priya." (Pak Priya: Guru matematika)

$P$ : "lha kamu benar-benar mendengarkan dan memperhatikan ndak?"

$O D$ : "sedikit...hehe"

$P$ : "Kenapa tidak banyak?"

$O D$ : "Males bu, udah nggak suka ma matematika"

$P \quad$ : "Kalau ada PR/tugas dikerjakan ndak? Lalu jika besoknya ada pelajaran matematika belajar ndak? Apa jika ada ulangan saja?"

$O D$ : "nggak pernah mengerjakan PR bu, belajar kalau ada ulangan saja..hehe”

$P \quad$ : "tipe soal kan ada beberapa tipe, kamu suka tipe apa? Kenapa?”

$O D$ : "pilihan ganda bu, bisa ngarang jawabannya"

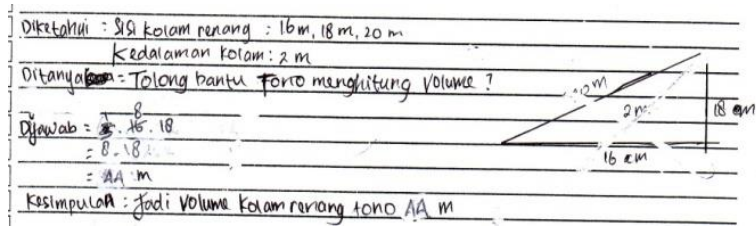

Gambar 3. Hasil kerja OD

Dari hasil wawancara seperti di atas, diperoleh informasi bahwa karakter kerja keras OD sangat rendah, ditunjukkan dengan tidak adanya semangat untuk menerima ilmu dari guru. Bahkan untuk mendengarkan penjelasan guru pun dia merasa keberatan. OD juga menjelaskan bahwa dia tidak pernah mengerjakan PR maupun tugas yang diberikan oleh guru, dengan begitu OD tidak pernah latihan mengerjakan soal sendiri di rumah. Dia hanya belajar jika keesokan hari ada ulangan.

Menurut keterangan guru pamong, OD tergolong siswa yang tidak rajin maupun disiplin. Hal ini ditunjukkan dalam kesehariannya bahwa OD sering membolos sekolah dalam waktu yang lama. Bahkan OD sering tidak mengikuti tambahan pelajaran yang disediakan sekolah setelah jam sekolah.

Tetapi setelah diterapkan pembelajaran konstruktivis dengan pendekatan inkuiri, OD menunjukkan peningkatan walaupun sedikit.
Peningkatan OD ditunjukkan dengan ketika pembelajaran pada saat peneliti meminta siswa mengerjakan soal dengan bantuan media, OD lumayan tertarik untuk melihat media. Walaupun ketika diminta untuk mengerjakan soal, OD hanya mencontek temannya saja, tetapi setidaknya dia sudah mau sedikit memperhatikan materi matematika.

Selama mengerjakan soal dengan cara berkelompok, OD tidak pernah ikut berdiskusi, tidak pernah mengeluarkan pendapat dan hanya menyalin jawaban dari teman sekelompoknya saja. Ketika peneliti bertanya pada OD apakah dia bisa mengerjakan, OD hanya tersenyum. Pada pertemuan berikutnya OD sudah mau memperhatikan media sembari mencocokkan ke soal, dalam diskusi kelompokpun OD sudah mau bertanya ke teman hasil yang diperoleh temannya itu caranya bagaimana. Pada saat peneliti bertanya ataupun sekedar mendekat ke kelompoknya, terkadang OD berani bertanya pada peneliti. Tetapi jika OD disuruh untuk maju ke depan untuk mengerjakan OD selalu menolak, dan hanya menjawab jika dia belum selesai mengerjakan. Dari wawancara, OD lebih menyukai soal pilihan ganda karena bisa mengarang jawaban, dia tidak suka mengerjakan soal berbentuk uraian karena harus memahami soal, menghafal rumus, menghitung, dan jika menyontek pasti akan ketahuan oleh guru.

\section{Cuplikan hasil wawancara dengan siswa AD}

$P \quad:$ :Apakah kamu suka matematika? Kenapa?"

$A D$ : "Suka, ada yang gampang ada yang susah"

$P \quad$ : "Susahnya kenapa?"

$A D$ : "Karena banyak rumusnya, kalo sukanya karena ada rumus yang gampang diingat"

$P \quad$ : "Hambatan dalam belajar matematika apa saja?"

$A D$ : "Karena rumusnya banyak tadi saja"

$P \quad$ : "Di rumah ada yang mengajari?"

$A D$ : "Ada, dengan saudara, lebih suka belajar di rumah, karena ada yang mengajari, kalau di sekolahan tidak nyaman jika bertanya berulangulang"

$P \quad$ : "Tipe soal yang disukai apa?"

$A D$ : "Soal pilihan ganda, karena ada pilihannya, kalau soal uraian kan harus tau rumusnya dulu."

$P \quad$ : "Suka soal cerita?"

$A D$ : "Lumayan, tapi kadang susah memahami soalnya." 


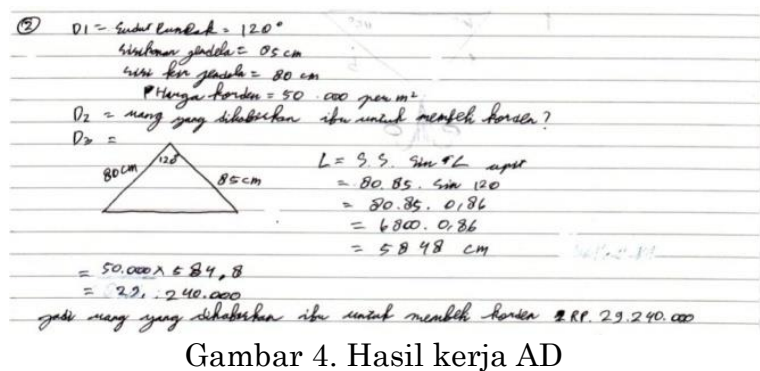

Dari hasil wawancara di atas, diperoleh informasi bahwa karakter kerja keras $\mathrm{AD}$ masih kurang. Ketika peneliti meminta siswa untuk memperhatikan dan mengerjakan soal-soal, AD lebih bergantung pada teman yang lebih pintar, tetapi sesekali $\mathrm{AD}$ masih bertanya pada temannya bagaimana cara mengerjakan.

Selama mengerjakan soal dengan cara berkelompok, AD mengalami kesulitan dengan pemahaman soal, tetapi setidaknya AD masih mau berusaha dalam memahami soal dengan kemampuan sendiri. Ketika teman-teman yang pintar mulai berdiskusi $\mathrm{AD}$ hanya mendengarkan saja. $\mathrm{AD}$ tidak terlibat dalam menyelesaikan masalah secara berkelompok. AD pun tidak terlihat mencari petunjuk untuk mengerjakan jawaban dari sumber lain.

Ketika peneliti bertanya pada $\mathrm{AD}$ apakah dia bisa mengerjakan, $\mathrm{AD}$ malah bertanya maksud soal kepada peneliti. Pada pertemuan berikutnya $\mathrm{AD}$ sudah sedikit berusaha meminta temannya untuk menerangkan maksud dari soal dan tidak hanya menunggu jawaban dari teman dan dia sudah berusaha menemukan apa yang diketahui dan apa yang ditanyakan dari soal. $\mathrm{AD}$ pun sudah bersedia membuka buku sumber lain selain membuka-buka media. Tetapi jika AD disuruh untuk maju ke depan untuk mempresentasikan AD selalu menolak, dan hanya menjawab jika dia belum selesai mengerjakan dan menunjuk teman lain yang dia anggap sudah selesai.

Cuplikan hasil wawancara dengan siswa EF

$-$

$\mathrm{P}$ : "Suka matematika?"

EF : "Suka, menurut saya menarik walaupun kadang agak susah tapi tetap menarik"

$P \quad$ : "Susahnya dimana?"

EF : "Susah kalau memahaminya saja"

$P \quad$ : "Kalau mengalami seperti itu apa yang kamu lakukan"

EF : "Kalau dulu ada yang ngajari kakak, tp skrg ga ada soalnya kakak kerja, sekarang paling tanya teman yang lebih pintar, kalau nggak tanya pak Priya saja langsung"

$P \quad$ : "Kalau bikin PR bikin sendiri?"

EF : "Iya bikin sendiri"

$P \quad$ : "Jika belajar saat ulangan saja?"

EF : "Belajar jika ada PR dan besok ada ulangan..hehe"

$P \quad$ : "Lebih suka suasana belajar yang bagaimana?"

EF : "Lebih suka belajar di suasana sepi"

$P \quad$ : "Tipe soal yang disukai?"

EF : "Soal pilihan ganda karena bisa pakai cara cepet, bisa memasukkan pilihan jawaban ke soal, kalau soal cerita susah karena susah memahami maksudnya"

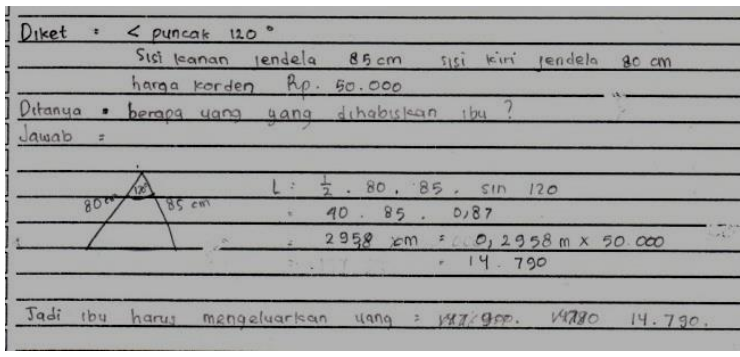

Gambar 5. Hasil kerja AD

Dari hasil wawancara diperoleh informasi bahwa EF sebenarnya cukup menyukai matematika. Karakter kerja keras EF pun termasuk lumayan walupun masih perlu ditingkatkan. Pada saat mengerjakan soal, EF sudah terlihat berusaha untuk mengerjakan soal dengan kemampuan sendiri, mencari sumber lain sendiri. Tetapi ketika sudah mendapatkan hasil jawaban, EF seperti tidak percaya dengan jawabannya sendiri dan sibuk mencocokan jawabannya dengan teman yang lebih pintar.

Ketika peneliti meminta EF untuk mengerjakan di depan, EF menolak dan mengatakan kalau dia takut jawabannya salah. Pertemuan berikutnya peneliti kembali berusaha agar EF bersedia mengerjakan di depan dengan mengatakan bahwa jika pekerjaannya salah EF tidak akan mendapatkan hukuman. Pada pertemuan berikutnya peneliti lebih memberikan pendekatan inkuiri dengan memberikan petunjuk-petunjuk agar EF yakin bahwa jawaban yang dibuatnya itu tepat, akhirnya EF bersedia mengerjakan di depan kelas.

Cuplikan hasil wawancara dengan siswa WA

$P \quad:$ "Menyukai matematika?"

WA : "Ya, bu kadang matematika itu mudah, tapi kalau pas dalam satu materi rumusnya banyak itu yang bikin susah, soalnya kalau materi baru rumusnya banyak, rumus dari materi yang lama itu jadi lupa

$P$ : "Lebih suka suasana belajar di rumah atau sekolah?" 
WA : "Rumah bu, lebih nyaman, di sekolah kadang berisik, rame"

$P \quad$ : "Di rumah selalu belajar atau kalau ada ulangan saja?"

WA : "Mengerjakan PR kan sudah belajar bu, tapi saya belajar jika ada ulangan saja"

$P \quad$ : "Lebih menyukai tipe soal apa?"

WA : "Pilihan ganda, soalnya bisa pakai cara cepat, masukin pilihan jawaban ke soal, kalau ada yang cocok berarti itu yang bener."

$P \quad$ : "Tidak suka soal cerita kenapa?"

WA : "Soalnya muter-muter bu, lebih suka soal langsung ke intinya saja, kalau soal cerita harus membayangkan dulu."

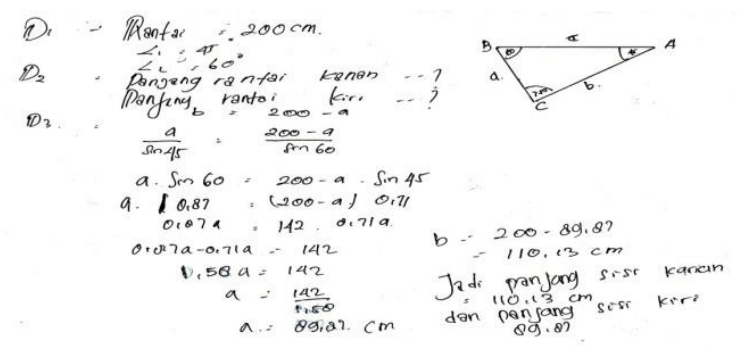

Gambar 6. Hasil kerja WA

Ketika peneliti meminta WA untuk mengerjakan soal di depan, pada pertemuan awal WA tidak bersedia menunjuk diri sendiri. Walaupun jika diperhatikan sebenarnya WA ingin maju tetapi sepertinya WA malu. Pada saat pembelajaran WA juga sering diminta temannya untuk menerangkan, tetapi jika dia sendiri tidak bisa, dia langsung bertanya dan meminta pendapat dari teman yang dianggapnya lebih pintar. Terkadang jika WA kurang memahami maksud dari temannya, dia juga membuka-buka buku dari sumber lain. Selanjutnya, pada pertemuan demi pertemuan berikutnya WA sudah tidak segan lagi bertanya kepada peneliti tentang bagaimana cara mengerjakan soal. Bahkan WA juga sudah mau menunjuk dirinya sendiri untuk maju mempresen-tasikan jawabannya.

Hasil wawancara dengan siswa AS

$P \quad:$ :Menyukai matematika? Kenapa?"

$A S$ : "Iya bu, soalnya matematika membantu saya pas ngerjain soal fisika sama kimia, tapi saya lebih suka kimia sebenernya"

$P \quad$ : "Ada kesulitan yang berarti ndak pada matematika?"

$A S$ : "Tidak ada bu"

$P \quad:$ :Lebih suka suasana belajar yang bagaimana?"

$A S$ : "Lebih suka yang tenang, paling enak itu belajar di kamar, kunci pintu biar nggak ada yang ganggu."

$P \quad$ : "Kalau di sekolah memangnya ada yang menganggu?"

$A S$ : "Temen-temen sukanya nanya-nanya terus bu, suruh nerangin terus saya."

$P$ : "Tiap hari belajar? Atau jika ada ulangan saja?"

AS : "Iya belajar bu tiap hari."
$P \quad$ : "Jika saat mengerjakan PR tidak bisa lalu apa yang kamu lakukan?”

$A S$ : "Biasanya besoknya tanya pak Priya."

$P \quad$ : "Tipe soal yang disukai apa?"

$A S$ : "Sama saja bu, tapi kadang soal cerita lebih asyik ndak cuma ada angka berapa-berapa terus dicari apa, kalau soal cerita kan ada ceritanya ndak bosen."

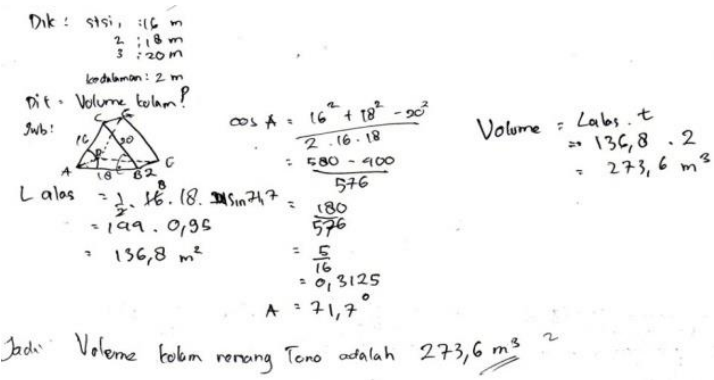

Gambar 7. Hasil kerja AS

Dari hasil wawancara diperoleh informasi bahwa AS menyukai matematika. Karakter kerja keras AS pun termasuk sangat bagus karena dia bersedia berusaha sungguhsungguh dengan kemampuannya sendiri. Pada saat mengerjakan soal, AS tergolong sama sekali tidak mengalami kesulitan.

Ketika peneliti meminta AS untuk mengerjakan di depan, AS bersedia langsung mengerjakan di depan kelas walaupun dia sendiri belum mengerjakan di bukunya. Tetapi tidak setiap pertemuan AS bersikap demikian. Kadang jika dia sudah selesai mengerjakan soal yang diberikan, AS lebih asik mencoba-coba soal yang ada pada media pembelajaran.

Pada saat berdiskusi AS yang lebih dominan dalam mengeluarkan pendapatnya. Tetapi ini malah membuat teman-teman dikelompoknya lebih sering diam dan hanya mendengarkan AS terutama yang berkemampuan rendah. Ketika dimintai tolong oleh temannya AS cenderung lebih menghindar dan hanya menjelaskan seperlunya saja.

Dari hasil pengamatan dan wawancara yang telah dijelaskan, tampak bahwa kelima siswa memiliki karakteristik yang berbeda. Start awal, pandangan mereka terhadap matematika juga tidak sama. Beberapa siswa memang tidak menyukai matematika, ada pula yang memang menyukai sejak awal. Kondisi awal siswa ini banyak berpengaruh pada karakter kerja keras yang ditunjukkan saat pembelajaran. Siswa yang sejak awal menyukai pelajaran matematika terlihat aktif bekerja menyelesaikan soal, menemukan langkah penyelesaian dan 
berinteraksi dengan teman-teman dalam kelompok. Siswa yang sejak awal tidak menyukai matematika, sebagian besar yang berasal dari tingkat kognitif rendah, tidak menunjukkan banyak perubahan dalam proses pembelajaran.

Hasil data dari lembar pengamatan karakter kerja keras kelima responden dalam tiga kali pembelajaran melalui model konstruktivis dan pendekatan inkuiri di olah dalam bentuk angka dan dianalisis menggunakan uji gain ternormalisasi untuk melihat pembentukan dan peningkatan karakter kerja keras dari peserta didik.

\begin{tabular}{cccc}
\hline Peserta & \multicolumn{3}{c}{ Gain Karakter Kerja Keras } \\
didik & I & II & III \\
\hline OD & 0,09 & 0,16 & 0,08 \\
kriteria & rendah & rendah & rendah \\
AD & 0,11 & 0,23 & 0,30 \\
kriteria & rendah & rendah & rendah \\
EF & 0,29 & 0,53 & 0,75 \\
kriteria & redah & sedang & tinggi \\
WA & 0,33 & 0,50 & $-0,43$ \\
kriteria & sedang & sedang & rendah \\
AS & 0,25 & 0,44 & 1,00 \\
kriteria & rendah & sedang & tinggi \\
\hline Tabel 1. Hasil uji gain ternormalisasi karakter \\
\multicolumn{4}{c}{ kerja keras responden } \\
\end{tabular}

Skor gain ternormalisasi hasil pengamatan kerja keras pada kelima siswa responden di atas menunjukkan bahwa rata-rata karakter kerja keras mereka telah tampak, dan bahkan meningkat. Pada responden OD dan AD meski kriteria karakter kerja keras masih pada level rendah, tetapi tampak peningkatan yang baik dari pertemuan satu sampai tiga. Pertumbuhan karakter kerja keras yang paling bagus tampak dari responden $\mathrm{EF}$ dan $\mathrm{AS}$, dengan skor yang meningkat cupuk signifikan, dan mencapai level tinggi di akhir pembelajaran. Responden WA pada awalnya menunjukkan peningkatan karakter kerja keras, tetapi pada akhir pembelajaran tampak penurunan yang sangat drastis, hal ini tentunya dipengaruhi banyak faktor lain. Berdasarkan hasil wawancara lanjutan, ditemukan bahwa responden WA sedang dalam kondisi tidak sehat ketika mengikuti pembelajaran terakhir, sehingga kurang bersemangat dan mempengaruhi karakter kerja keras yang tampak.
Secara umum karakter kerja keras dari lima responden yang diamati telah muncul, dan beberapa diantaranya meningkat dengan baik. Salah satunya karena pelaksanaan pembelajaran matematika konstruktivis dengan pendekatan inkuiri dalam pembelajaran matematika yang telah dirancang sebelumnya, atau by design.

\section{KESIMPULAN DAN SARAN}

Pendidikan matematika yang terus berkembang, juga kebutuhan bangsa akan generasi-generasi berkarakter, menuntut guru sebagai praktisi pendidikan untuk lebih inovatif dan kreatif dalam pembelajaran. Pendidikan karakter yang terintegrasi dalam pembelajaran khususnya matematika, diharapkan lebih dikembangkan melalui berbagai model, metode, strategi, dan pendekatan. Pembelajaran by design semacam ini menjadi salah satu solusi dari harapan pemerintah kaitannya dengan pendidikan karakter.

Pembelajaran matematika dengan model konstruktivis dilengkapi pendekatan inkuiri dapat menjadi salah satu pilihan bagi guru untuk mengintegrasikan pendidikan karakter khususnya karakter kerja keras dalam pembelajaran matematika.

\section{DAFTAR PUSTAKA}

Fadillah, S. (2013). Pembentukan Karakter Responden melalui pembelajaran matematika. Jurnal pendidikan Matematika Paradikma, 6(2), 142-148.

Hubberman, M. dan Milles. (1992). Analisis Data Kualitatif. Jakarta: UI Press.

Kemendiknas. (2003). UU No. 20 tentang Sistem Pendidikan Nasional.

Kurniyati, H. (2013). Kerja Keras dalam Belajar, (Online), (http:/hestikurniyati.blogspot.com/2013/ 01/kerja-keras-dalambelajar.html., diakses 5 September 2016).

Moleong, L. (2009). Metode Penelitian Kualitatif. Bandung: PT. Remaja Rosdakarya. 
Putrayasa. (2009). Pengertian Model Inkuiri. http://ipotes.wordpress.com (Diakses 16 Agustus 2016. Pukul 20.05 WIB)

Richardson, V. (2003). Constructivist Pedagogy. Tachers College Record, 105(9), 1623-1640.

Sagala, S. (2006). Konsep dan Makna Pembelajaran. Bandung: Alfabeta.

Soedjadi. (2000). Kiat Pendidikan Matematika di Indonesia: Konstatasi Keadaan Masa Kini Menuju Harapan
Masa Depan. Jakarta: Direktorat jenderal Pendidikan Tinggi, Departemen Pendidikan Nasional.

Sugiyono. (2008). Metode Penelitian Kuantitatif, Kualitatif, dan R\&D. Bandung: Alfabeta. 